\title{
Male Breast Cancer: Prognosis and Survivorship
}

\author{
Ali Jad Abdelwahab Yousef* \\ General Surgery Department, Mutah University, Jordan
}

Submission: March 18, 2018; Published: March 27, 2018

"Correspondence Address: Ali Jad Abdelwahab Yousef, General Surgery Department, Faculty of Medicine, Mutah University, Postal Code: 61710, Karak, Jordan, Tel: 0096232372380/6000; Fax: 0096232375540; Email: alijad30@hotmail.com

\begin{abstract}
The purpose of this review was to explore the prognosis and prognostic factors for male breast cancer in depth and to discuss the survivorship issues which are seldom discussed in literature. Search in Medline and Google Scholar for male breast cancer epidemiology, prognosis, and survivorship resulted in tremendous number of articles discussing the epidemiology of male breast cancer, but limited number of articles discussed survivorship issues within the context of other subjects. The prognosis of male breast cancer is dependent on the lymph nodes status and disease stage. Survivorship issues are as important as treatment of the cancer itself. The risk of the male contra lateral breast cancer is much higher than in the female breast cancer, so the patients should be aware of the necessity of close follow up. The long term effects of treatment are variable, but most of them are potentially curable.
\end{abstract}

Keywords: Male breast cancer; Prognosis; Survivorship; Therapy side effects

Abbreviations: FBC: Female Breast Cancer; MBC: Male Breast Cancer; DFS: Disease-Free Survival; OS: Overall Survival; VTE: Venous Thromboembolism

\section{Prognosis of Male Breast Cancer}

The most significant prognostic factors for male breast cancer are lymph node involvement and stage of MBC at diagnosis. The overall 5-year survival rates are around 40-65\%, and when estimated for stage at presentation, 5-year survival is $75-100 \%$ for stage I, $50-80 \%$ for stage II, and $30-60 \%$ for stage III [1]. When matched for age, lymph nodes status and stage, male and female breast cancers have nearly similar prognosis differences in terms of disease free survival (DFS) or overall survival (OS) $[2,3]$. The more lymph node number involved, the less favorable the prognosis will be. The reported five year survival rates for node negative diseases have been $90 \%$; for one to three involved lymph nodes 73\%; and for four or more lymph nodes 55\% [4]. As in female breast cancer, tumor grade is a strong prognostic variable [5]. In the series reported by McLachlan et al. [6]; 5-year survival for grade 2 tumors was $58 \%$ and for grade 3 tumors was $45 \%$, and in the series reported by Pich et al. [7]; the median survival was 72 months with grade 2 tumors and 33 months with grade 3 tumor.

It is unknown yet whether biologic markers are having the same prognostic significance in both sexes. In males, some studies have shown no relation between survival and HER2 status [8,9] while others demonstrated that positive HER2 pointed towards a shorter disease free or overall surviva $[10,11]$. Progesterone receptor status and lymphovascular invasion have not been proven to influence prognosis $[12,13]$. Androgen receptor positivity link to prognosis is controversial [14,15], while over expression of cyclin D1 and c-myc may could be linked to a better prognosis [16]. Male breast cancers associated with BRCA2 mutations have a poorer prognosis [17].

Socio-demographic factors of prognosis are effective in male breast cancer patients but not in the same pattern as in female breast cancer in that black men rather than white, and men living in non-metropolitan areas are probably having a worse prognosis $[18,19]$. Overall, men have a worse prognosis than women because of the advanced disease at diagnosis. Other prognostic factors related to poor outcome in MBC are the older age at presentation and the presence of co morbidities which may limit some treatment options $[1,20]$.

\section{Survivorship Issues}

An individual is considered a cancer survivor from the time of diagnosis till he /or she achieves balance of his /or her life. Survivorship issues can be divided into two broad categories:

i. Management of therapy long-term sequelae, and

ii. Surveillance.

\section{Management of Therapy Long-Term Sequelae}

\section{Compliance to endocrine therapy}

At least $25 \%$ of men with breast cancer discontinue hormonal therapy due to its side effects such as sexual dysfunction and hot 
flashes [21,22]. The commonest side effects of tamoxifen are hot flashes, decreased libido, deep vein thrombosis, pulmonary embolism, weight gain, fatigue, depres $\neg$ sion, and skin rash, and the commonest side effects of aromatase inhibitors are hot flashes, decreased libido, depression, and peripheral edema [22]. Non compliance with hormonal treatment will eliminate the therapeutic benefit, so health care providers need to understand the treatment side effects and the patient's responses in order to encourage adherence to treatment and commitment to healthy life style including suitable physical exercises and keeping a normal body weight.

\section{Bone health}

Aromatase inhibitors are known to cause bone loss and fractures in women [23], contrasting tamoxifen which causes osteopenia in premeno $p$ pausal women and enhances bone density in postmenopausal women. The National Comprehensive Cancer Network (NCCN) guidelines recommend periodic bone mineral density testing in females on aromatase inhibitor therapy. The importance of bone mineral density testing in male survivors is not determined yet.

\section{Hot flashes}

The available data of hot flashes treatment has come from studies in FBC survivors, and further correlations may be needed in MBC survivors. Lifestyle modifications such as sleeping in a cool room and some medications such as venlafaxine or citalopram may be beneficial [24]. About $60 \%-80 \%$ of prostate cancer patients on anti- androgen therapy may have hot flashes; thus the available evidence on hot flashes treatment in prostate cancer patients may give clue for future recommendations for MBC patients receiving hormonal therapy [25].

\section{Sexual dysfunction}

Erectile dysfunction and loss of libido are serious concerns for many MBC survivors. These sexual dysfunctions could occur due to hormonal manipulation and surgery changing body image [26]. Lifestyle modifications such as reducing weight, quitting smoking and alcohol consumption may help some patients; others may benefit from counseling or phosphodiesterase type 5 inhibitors. Reconstructive surgeries may be offered as an option for patients occupied with the idea of mutilated body image.

\section{Emotional distress}

Some males feel shame to have a woman's cancer, and the situation may be more complicated when they find other male survivors with whom to establish support group.

\section{Cardiotoxicity}

Cardiotoxicity in MBC survivors is not well-studied. However, the NCCN Survivorship Guidelines proาvide guidance for evaluation and management of the heart problems (especially heart failure) after cancer treatment with anthracycline or HER2 targeted therapy [27]. Many female and male breast cancer patients who receive anthracycline and/or trastuzumab are at an increased for developing pump failure in the presence of other risk factors for cardiac disease. Risk management, early detection, and cardio-protective agents might help optimize cardiac function on the long term [28].

\section{Venous thromboembolism}

Tamoxifen is well-known to be an independent risk factor for venous thromboembolism (VTE) [29]. Therefore, a detailed history searching for thromboses risk factors should be obtained before starting hormonal therapy in MBC patient.

\section{Surveillance}

\section{Breast imaging}

There is no role for breast cancer screening in the general male population because it is a rare cancer. But, on the other hand, the risk of developing contra lateral male breast cancer for those who had previous cancer is 30-fold more than the general population while in women it is two to four folds, [30] so screening for the contralateral breast in male survivor is of up most importance.

\section{Second cancers}

MBC survivors are at increased risk of other non-breast second cancers including prostate, renal, lung, colorectal, esophageal, gastric, leukemia, and sarcoma cancers. The median age at diagnosis of the second primary is 70 years [31,32].

\section{Cancer screening recommendations}

There are no established screening programs in $\mathrm{MBC}$ as for FBC patients.

\section{Genetic testing recommendations}

Because of strong association between BRCA2 mutations and male breast cancer, the NCCN guidelines recommend genetic counselᄀing and testing for all male breast cancer survivors based on their risk of carrying a deleterious mutation that might be relevant to their personal follow up or the care of other family members. [27].

\section{Conclusion}

Survivorship issues are part of MBC treatment, namely treatment of the side effects of chemotherapy, hormonal therapy, and radiotherapy. The other facet of survival care is the close surveillance for the other breast cancer and/or second cancers. Both of these aspects are actually the tertiary prevention of male breast cancer.

\section{References}

1. Ribeiro GG, Swindell R, Harris M, Banerjee SS, Cramer A (1996) A review of the management of the male breast carcinoma based on an analysis of 420 treated cases. The Breast 5(3): 141-146.

2. Foerster R, Foerster FG, Wulff V, Schubotz B, Baaske D, et al. (2011) Matched-pair analysis of patients with female and male breast cancer: a comparative analysis. BMC Cancer 11: 335. 


\section{Cancer Therapy \& Oncology International Journal}

3. Miao H, Verkooijen HM, Chia KS, Bouchardy C, Pukkala E, et al. (2011) Incidence and outcome of male breast cancer: an international population-based study. J Clin Oncol 29(33): 4381-4386.

4. Guinee VF, Olsson H, Moller T, Shallenberger RC, van den Blink JW, et al. (1993) The prognosis of breast cancer in males. A report of 335 cases. Cancer 71(1): 154-161.

5. Chiusa L, Margaria E, Pich A (2000) Nuclear morphometry in male breast carcinoma: association with cell proliferative activity, oncogene expression, DNA content and prognosis. Int J Cancer 89(6): 494-499.

6. Sue-Anne McLachlan, Charles Erlichman, Fei-Fei Liu, Naomi Miller Melania Pintilie (1996) Male breast cancer: an 11 year review of 66 patients. Breast Cancer Res Treat 40(3): 225-230.

7. Pich A, Margaria E, Chiusa L (1994) Proliferative activity is a significant prognostic factor in male breast carcinoma. Am J Pathol 145(2): 481489

8. Mourão Netto $\mathrm{M}$, Logullo $\mathrm{AF}$, Nonogaki $\mathrm{S}$, Brentani RR, Brentani MM (2001) Expression of c-erbB-2, p53 and c-myc proteins in male breast carcinoma: comparison with traditional prognostic factors and survival. Braz J Med Biol Res 34(7): 887-894.

9. Idelevich E, Mozes M, Ben-Baruch N, Huszar M, Kruglikova A, et al (2003) Oncogenes in male breast cancer. Am J Clin Oncol 26(3): 259261

10. Pich A, Margaria E, Chiusa L (2000) Oncogenes and male breast carcinoma: c-erbB-2 and p53 coexpression predicts a poor survival. J Clin Oncol 18(16): 2948-2956.

11. Wang-Rodriguez J, Cross K, Gallagher S, Djahanban M, Armstrong JM, et al. (2002) Male breast carcinoma: correlation of ER, PR, Ki-67, Her2$\mathrm{Neu}$, and p53 with treatment and survival, a study of 65 cases. Mod Pathol 15(8): 853-861.

12. Meijer-van Gelder ME, Look MP, Bolt-de Vries J, Peters HA, Klijn JG, et al. (2001) Clinical relevance of biologic factors in male breast cancer Breast Cancer Res Treat 68: 249-260.

13. de Ieso PB, Potter AE, Le H, Colin Luke, Raghavendra V Gowda (2012) Male breast cancer: a 30-year experience in South Australia. Asia Pac J Clin Oncol 8(2): 187-193.

14. Pich A, Margaria E, Chiusa L, Candelaresi G, Dal Canton O (1999) Androgen receptor expression in male breast carcinoma: lack of clinicopathological association. Br J Cancer 79(5-6): 959-964.

15. Shaaban AM, Ball GR, Brannan RA, Cserni G, Di Benedetto A, et al. (2012) A comparative biomarker study of 514 matched cases of male and female breast cancer reveals gender-specific biological differences Breast Cancer Res Treat 133(3): 949-958.

16. Kanthan R, Fried I, Rueckl T, Senger JL, Kanthan SC (2010) Expression of cell cycle proteins in male breast carcinoma. World J Surg Oncol 8: 10 .

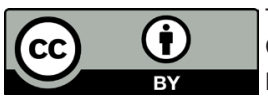

This work is licensed under Creative

Commons Attribution 4.0 License

DOI: 10.19080/CTOIJ.2018.10.555776
17. Kwiatkowska E, Teresiak M, Filas V, Karczewska A, Breborowicz D, et al. (2003) BRCA2 mutations and androgen receptor expression as independent predictors of outcome of male breast cancer patients. Clin Cancer Res 9(12): 4452-4459.

18. Crew KD, Neugut AI, Wang X, Jacobson JS, Grann VR, et al. (2007) Racial disparities in treatment and survival of male breast cancer. J Clin Oncol 25(9): 1089-1098.

19. Klein J, Ji M, Rea NK, Stoodt G (2011) Differences in male breast cancer stage, tumor size at diagnosis, and survival rate between metropolitan and nonmetropolitan regions. Am J Mens Health 5(5): 430-437.

20. Donegan WL, Redlich PN, Lang PJ, Gall MT (1998) Carcinoma of the breast in males. Cancer 83(3): 498-509.

21. Anelli TF, Anelli A, Tran KN, Lebwohl DE, Borgen PI (1994) Tamoxifen administration is associated with a high rate of treatment-limiting symptoms in male breast cancer patients. Cancer 74(1): 74-77.

22. Visram H, Kanji F, Dent SF (2010) Endocrine therapy for male breast cancer: rates of toxicity and adherence. Curr Oncol 17(5): 17-21.

23. Bauer M, Bryce J, Hadji P (2012) Aromatase inhibitor-associated bone loss and its management with bisphosphonates in patients with breast cancer. Breast Cancer 4: 91-101.

24. Sideras K, Loprinzi CL (2010) Nonhormonal management of hot flashes for women on risk reduction therapy. J Natl Compr Canc Netw 8(10): 1171-1179.

25. Schow DA, Renfer LG, Rozanski TA, Thompson IM (1998) Prevalence of hot flushes during and after neoadjuvant hormonal therapy for localized prostate cancer. South Med J 91(9): 855-857.

26. Ruddy KJ, Giobbie-Hurder A, Giordano SH (2013) Quality of life and symptoms in male breast cancer survivors. Breast 22(2): 197-199.

27. Network NCC (2017) Survivorship. NCCN Clinical Practie Guidelines in Oncology.

28. Cardinale D, Colombo A, Bacchiani G, Tedeschi I, Meroni CA, et al. (2015) Early detection of anthracycline cardiotoxicity and improvement with heart failure therapy. Circulation 131(22): 1981-1988.

29. Lipton A, Harvey HA, Hamilton RW (1984) Venous thrombosis as a side effect of tamoxifen treatment. Cancer Treat Rep 68(6): 887-889.

30. Auvinen A, Curtis RE, Ron E (2002) Risk of subsequent cancer following breast cancer in men. J Natl Cancer Inst 94(17): 1330-1332.

31. Cutuli B, Le-Nir CC, Serin D, Kirova Y, Gaci Z, et al. (2010) Male breast cancer. Evolution of treatment and prognostic factors. Analysis of 489 cases. Crit Rev Oncol Hematol 73(3): 246-254.

32. Masci G, Caruso M, Caruso F, Salvini P, Carnaghi C, et al. (2015) Clinicopathological and immunohistochemical characteristics in male breast cancer: a retrospective case series. Oncologist 20(6): 586-592.

Your next submission with Juniper Publishers will reach you the below assets

- Quality Editorial service

- Swift Peer Review

- Reprints availability

- E-prints Service

- Manuscript Podcast for convenient understanding

- Global attainment for your research

- Manuscript accessibility in different formats

( Pdf, E-pub, Full Text, Audio)

- Unceasing customer service

Track the below URL for one-step submission https://juniperpublishers.com/online-submission.php 